\title{
ORIGINAL
}

\section{Pyrolysis Behaviors and Thermostability of Polyglycerols and Polyglycerol Fatty Acid Esters}

\author{
Toshiaki Ushikusa*, Takenori Maruyama*, Isao NiryA*, and Masakazu OKadA** \\ * Japan Institute of Oils \& Fats, Other Foods Inspection, Foundation \\ (3-27-8, Nihonbashi-Hamacho, Chuo-ku, Tokyo, ₹103) \\ ** Faculty of Applied Biological Science, Hiroshima University \\ (Saijo-cho, Higashi-Hiroshima-shi, Hiroshima-ken, T724)
}

\begin{abstract}
The weight loss behavior of commercial polyglycerols (PG) and $P G$ with various degrees of polymerization, and polyglycerol fatty acid ester (PGFE) with various carbon numbers of acyl group and various degrees of esterification was studied by means of dynamic programmed thermogravimetry (TG). The relationship between the ratio of weight loss at various temperatures and component compositions was also studied by PG. The thermostability of PGFE was evaluated from the temperature of weight loss initiation in dynamic programmed TG, and from the decomposition time-required for a $5 \%$ weight loss in isothermal TG. The results are summarized as follows :
\end{abstract}

1) The temperature of weight loss initiation shifted to the higher temperature side and thermostability was enhanced with increase in the degree of polymerization in the programmed TG of PG. Commercial PG, after removal of water, showed characteristic weight loss pattern depending on the composition of polymerization.

2) The ratios of weight loss of $\mathrm{PG}$ at room temperature $\sim 150^{\circ} \mathrm{C}, 150 \sim 250^{\circ} \mathrm{C}, 250 \sim 300^{\circ} \mathrm{C}$, and $300 \sim 350^{\circ} \mathrm{C}$ were also correlated with the content of water, monoglycerol, the sum of di- and triglycerols, and the sum of tetra- and pentaglycerols in programmed TG, respectively.

3) The temperature of weight loss initiation shifted slightly to the higher temperature side with increase in the carbon number of the acyl group in the programmed TG of PGFE. The TG curves from 300 to $400^{\circ} \mathrm{C}$ showed characteristic weight loss patterns for PGFE with various degrees of esterification, but there was no correlation between the weight loss pattern and degrees of esterification.

4) The heat resisting time of PGFE at various temperature was essentially independent of the carbon number of the acyl group as was observed in isothermal TG. However, heat resisting time was reduced and thermostability decreased with increase in the degree of esterification.

\section{Introduction}

Polyglycerols (PG) have been used as emulsifiers for food for a long time in western countries. However, the use of PG as food additives are not approved in our country. Thus, the major portion of $P G$ produced are used as the starting materials in the production of polyglycerol fatty acid esters (PGFE). In the fields other than food industry, $P G$ have been used as raw material of cosmetics such as creams or the like because these are the excellent humectant.

PGFE, synthesized from $P G$, are the raw materials for the production of various products possessing the properties either hydrophilic or lipophilic, produced by changing the degree of polymerization and esterification, and kinds of acyl groups. PGFE possess property with excellent safety ${ }^{11}$, and therefore, $80 \%$ or more of them are consumed for food industry. PGFE are useful not only for the emulsifiers but also for the viscosity depressants as well as for the crystallization controllers ${ }^{2,3)}$. Furthermore, PGFE are expected to be used in the field of cosmetics, drugs, and polymer ${ }^{2}$ because of their excellent acidresistance, hydrolysis-resistance, and heatresistance properties. $\mathrm{GLC}^{4)}$ and $\mathrm{HPLC}^{2,5)}$ are used to determine the composition of $P G$ and PGFE in order to evaluate their quality. However, the PG which can be analyzed accuarately at present are only up to pentaglycerol by GLC, while up to decaglycerol by $\mathrm{HPLC}^{2)}$. On the other hand, the PGFE which can be analyzed by GLC are limited only to mono- and 
diester of triglycerol even if these are converted in to the TMS derivatives ${ }^{21}$, whereas the PGFE can be analyzed by HPLC only roughly up to the triester. We have, therefore, utilized the dynamic programmed thermogravimetry( $\mathrm{TG}$ ) for the analysis of $P G$ and PGFE in this study in order to determine the polymer compositions of $P G$, and to estimate the carbon number of acyl groups and the degree of esterification of PGFE on the basis of the initial temperature of weight loss and the weight loss behaviors on TG curve. Furthermore, we have examined the adaptability of $\mathrm{TG}$ for the qualitative evaluation of PG and PGFE in their manufacturing process. In addition, the thermostabilities of PGFE were examined by isothermal $\mathrm{TG}$ as described previously ${ }^{6)}$ since PGFE are used as antiaging agent or dough modifiers in the production of bread and cakes.

\section{Experimental}

\subsection{Materials}

Four commercial PG used possess different degrees of polymerization: PG-A, B, C and D.

Table-1 showed the water content of these samples determined by the Karl-Fischer method ${ }^{7)}$ and polymer compositions determined by HPLC equipped with an aqueous GPC column (Shodex, S-801). These PG samples with differnt degree of polymerization were prepared from the commercial PG-A, B and D by fractionating their major peak in the HPLC mentioned above. The three samples thus prepared were the mixtures composed of di- and triglycerols, tetra- and pentaglycerols, and octa-, nona-, and decaglycerols, respectively. The purity of component polyglycerols in each mixture were above $90 \%$ as determined by HPLC. The monoglycerol examined simultaneously was that of the biochemical reagent grade (Nakarai Chemical Co., Kyoto).

Three PGFE having lauric acid(PG-C12), palmitic acid(PG-C16), and stearic acid(PG-18) as acyl groups in the monoacyl ester portion were used as the samples. The saponification value of each sample determined by JOCS Standard Method $^{81}$ was almost identical with the calculation value of the corresponding monoester. For the PGFE with different degree of esterification, five $\mathrm{PGFE}$ having stearic acid as acyl groups were used as the samples. The PGFE having saponification value of $76,97,131,154$, and 167 were reffered to as monoester (PG-Mo), diester (PG-Di), triester (PG-Tr), pentaester (PG-Pe), and heptaester (PG-He), respectively. After saponification of $\mathrm{PGFE}$ with the conventional method, a portion of PG was analyzed by HPLC, whereas a portion of fatty acids was analyzed by GLC as the methyl ester derivatives. The PG was found to have the mejor component of hexaglycerol (above $85 \%$ ) in each PGFE. Regarding the constituent fatty acids, lauric acid in PG-C12 was above $99 \%$, palmitic acid in PG-C16 was above $96 \%$, and stearic acid in PG-C18, PG-Mo, PG-Di, PG-Tr, PG-Pe and PG-He were above $97 \%$. These PGFE were courteously donated as the gifts by Sakamoto Chemical Industries Co. (Osaka).

\section{$2 \cdot 2$ Analytical method}

The instrument and their operating conditions of the dynamic programmed TG and the isothermal TG used in this study were the same to those previously reported ${ }^{6)}$. The heat resisting time in isothermal TG was expressed in the decomposition time from initial to that with $5 \%$ of weight loss after reaching the temperature of determination, and hence, the thermostability could be evaluated by the heat resisting time, as described previously ${ }^{6}$. The determination temperature was lowered by every 10 or $5^{\circ} \mathrm{C}$ from $265^{\circ} \mathrm{C}$.

\section{Results and Discussion}

\section{$3 \cdot 1$ Pyrolysis behavior of $\mathbf{P G}$ in dynamic programmed TG}

$3 \cdot 1 \cdot 1$ Difference due to degrees of polymerization

Fig.-1 showed TG curves of the monoglycerol, and the mixture of di-and triglycerols, tetra- and pentaglycerols, and octa-, nona-, and decaglycerols provided by HPLC fractionation. The weight loss of the monoglycerol initiated at $53^{\circ} \mathrm{C}$ which was unexpected since the boiling point of monoglycerol is $290^{\circ} \mathrm{C}^{9}$. The water content of monoglycerol determined by Karl-Fischer method ${ }^{7)}$ was about $2.7 \%$. The ratio of weight loss at the temperature range of room temperature $100^{\circ} \mathrm{C}$, i.e., the boiling point of water, calculated from TG curve was about $1.5 \%$ and this was lower than that determined by Karl-Fischer method. This might be due to the fact that the evaporation of water was attained not completely 
Table-1 The water content and polymer composition of commercial polyglycerols.

\begin{tabular}{l|c|c|c|c|c|c}
\hline & Water content & \multicolumn{5}{|c}{ Polymer composition (\%) } \\
\cline { 3 - 7 } & $(\%)$ & mono & di+tri & tetra+penta & hexa+hepta & $\geqq$ octa \\
\hline PG-A & 1.2 & 7.2 & 70.5 & 22.3 & 0.0 & 0.0 \\
PG-B & 4.8 & 9.0 & 24.2 & 32.6 & 23.6 & 10.6 \\
PG-C & 9.8 & 1.4 & 10.3 & 27.2 & 34.1 & 27.0 \\
PG-D & 10.7 & 4.1 & 15.0 & 17.4 & 21.2 & 42.3 \\
\hline
\end{tabular}

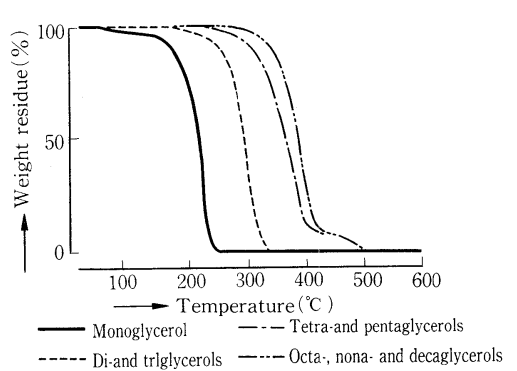

Fig.-1 TG curves of glycerols with various degrees of polymerization.

since the determination time of $\mathrm{TG}$ from room temperature to $100^{\circ} \mathrm{C}$ was short for about $14 \mathrm{~min}$.

However, this weight loss might be caused by the evaporation of water, similar to the case of household margarines reported previousely ${ }^{10)}$. After the evaporation of water, the weight loss of the monoglycerol initiated at about $150^{\circ} \mathrm{C}$, proceeded most rapidly at above $180^{\circ} \mathrm{C}$ which was caused by the volatilization of monoglycerol, and was finished at $248^{\circ} \mathrm{C}$. In the case of the fraction of diand triglycerol mixtures, the weight loss initiated at $167^{\circ} \mathrm{C}$ and proceeded most rapidly at about $250^{\circ} \mathrm{C}$. This weight loss pattern was a simple, and similar to that monoglycerol. The weight loss of tetra- and pentaglycerol mixture, and octa-, nona-, and decaglycerol mixture initiated at $223^{\circ} \mathrm{C}$ or $262^{\circ} \mathrm{C}$, respectively. On the former mixture, the weight loss behavior from the initial to that with $50 \%$ of weight loss proceeded slowly, than those of the monoglycerol and the other two fractions of mixtures. The weight loss of the fraction of tetra- and pentaglycerol mixtures, and the octa-, nona-, and decaglycerol mixtures proceeded slowly after $90 \%$ of weight loss, than those of monoglycerol and the fraction of di- and triglycerol mixtures. The weight loss pattern of these fractions were found to be somewhat complicated.

Thus, initial temperature of weight loss and the

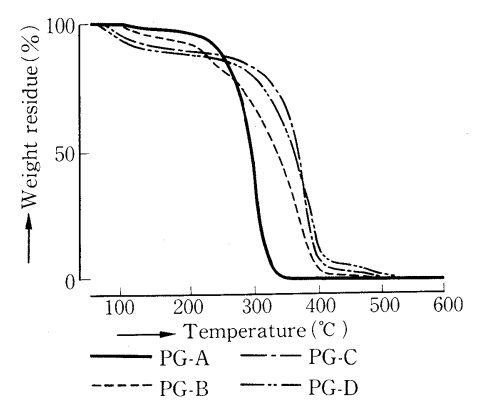

Fig.-2 TG curves of commercial polyglycerols.

TG curve of PG were shifted to higher temperature side, accompanied with the increase of the heat resisting temperature, and the increase of degree of polymerization.

Fig.-2 showed the TG curves of the commercial $P G$. The weight loss of each commercial PG began at a low temperature, which might be caused by the evaporation of water which contained. After the completion of the evaporation of water, the initial temperature of weight loss of each $P G$ was indistinguishable from one another until it was initiated weight loss caused by the volatirization of monoglycerol and polymer of low degrees of polymerization. However, the weight loss behaviors of individual PG were differed by the degree of polymerization. The weight loss of PG-A proceeded rapidly within a temperature range of $250 \sim 320^{\circ} \mathrm{C}$. On the other hand, the weight loss of $\mathrm{PG}-\mathrm{B}$ containing a somewhat larger amonut of monoglycerol than $\mathrm{PG}$-A became rapidly at about $250^{\circ} \mathrm{C}$ and proceeded most rapidly within a temperature range of $350 \sim 400^{\circ} \mathrm{C}$. The weight loss of $\mathrm{PG}-\mathrm{C}$ containing the smallest amounts of mono-, di- and triglycerol was the slowest until below $300^{\circ} \mathrm{C}$ and proceeded rapidly in the temperature ragion about $300^{\circ} \mathrm{C}$. The $\mathrm{TG}$ curve until the temperature of $50 \%$ of weight loss for PG-D containing more mono-, di- and triglycerol than PG-C, was located at lower temper- 
ature side when compared with PG-C. However, because of a large amount of components of higher degree of polymerization than PG-C, the TG curve of $\mathrm{PG}-\mathrm{D}$ in high temperature region over temperature of $75 \%$ of weight loss was shifted to higher temperature side.

As mentioned above, the weight loss behavior of individual commercial PG differed characteristically by their water content and polymer composition with one another. The weight loss behavior after the evaporation of water and the temperature of $50 \%$ of weight loss were well agreed with the data reported by Shioyama $e t a l^{11}$. who examined anhydrides of commercial PG by TG.

$3 \cdot 1 \cdot 2$ Simultaneous determination of water and monoglycerol in $\mathrm{PG}$

The samples by adding 4.0 to $21.7 \%$ of water and 9.5 to $24.2 \%$ of monoglycerol to the commercial PG-A, were determined the content of water and monoglycerol by TG. Fig.-3 showed the relationship between the amounts of water added and the ratio of weight loss at the temperature ranges of room temperature to 125,150 , and $170^{\circ} \mathrm{C}$. In the dynamic $\mathrm{TG}$ of $\mathrm{PG}$ with different degree of polymerization, the initial temperature of weight loss and the temperatures of 25,50 , and $75 \%$ of weight loss were significantly different from one another. The evaporation of water was not finished at a temperature range of room

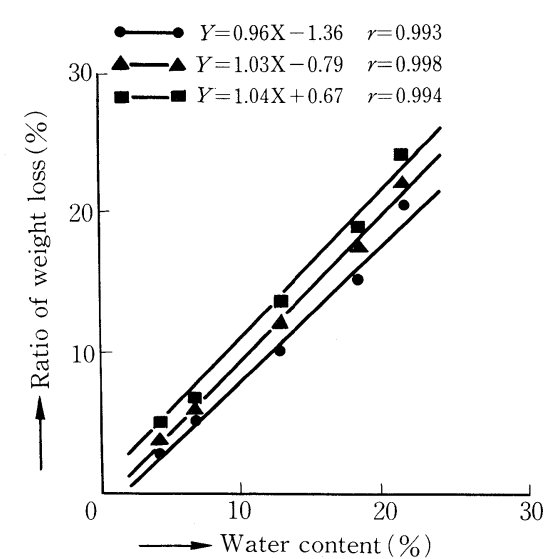

- A temperature range of room temperature $\sim 125^{\circ} \mathrm{C}$

$\Delta$ A temperature range of room temperature $\sim 150^{\circ} \mathrm{C}$

- A temperature range of room temperature $\sim 175^{\circ} \mathrm{C}$

Fig.-3 Relationships between the amount of water added and the ratio of weight loss at each temperature range.

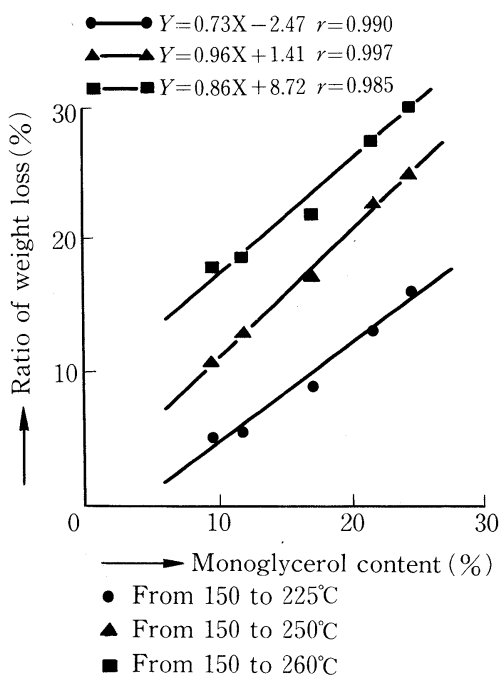

Fig.-4 Relationships between the amount of monoglycerol added and the ratio of weight loss at each temperature range.

temperature $\sim 125^{\circ} \mathrm{C}$, and therefore the ratio of the weight loss had somewhat lower value. The ratio of weight loss until $175^{\circ} \mathrm{C}$ had somewhat higher value because of the volatilization of monoglycerol simultaneousely occurred. The ratio of weight loss at a temperature range between room temperature to $150^{\circ} \mathrm{C}$ was agreed well with the amount of the water added. Fig.-4 showed the relationship between the amount of monoglycerol and the ratio of weight loss above $150^{\circ} \mathrm{C}$. Although the ratio of weight loss at each temperature range showed high correlation to the amount of monoglycerol added. It was found that the ratio of weight loss from 150 to $250^{\circ} \mathrm{C}$ was the most reliable.

Then, this relationship was applied to the commercial PG. As a result, ratio of weight loss until $150^{\circ} \mathrm{C}$ showed high correlation to the water content $(r=0.986)$ and the ratio of weight loss at a temperature range of $150 \sim 250^{\circ} \mathrm{C}$ showed high correlation to monoglycerol content $(r=0.992)$. In the similar manner, the ratio of weight loss at a temperature range of $250 \sim 300^{\circ} \mathrm{C}$ or $300 \sim 350^{\circ} \mathrm{C}$ showed high correlation to the sum of $\mathrm{di}$ - and triglicerol $(r=0.995)$ or the sum of tetra- and pentaglycerol $(r=0.951)$.

\section{$3 \cdot 2$ Pyrolysis behavior of PGFE in dynamic programmed TG}

Fig.-5 showed the TG curve of PG-C16 as an example of PGFE with various acyl groups. The 


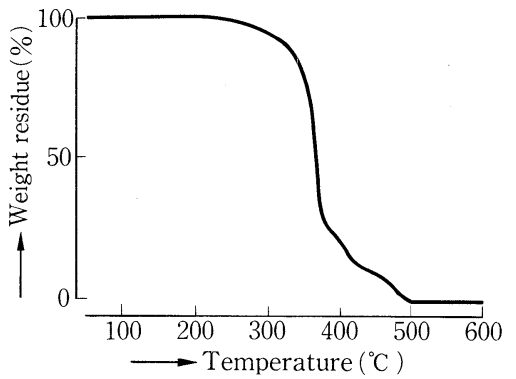

Fig.-5 TG curve of polyglycerol ester monopalmitic acid.

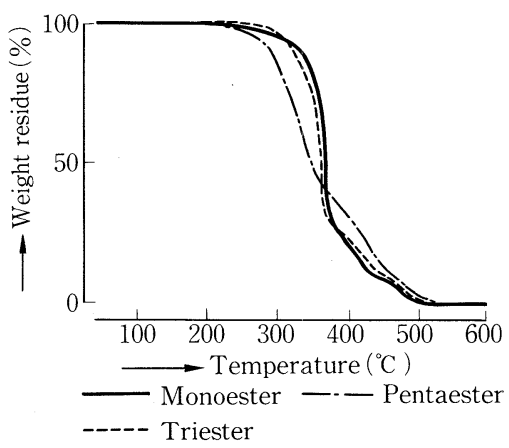

Fig.-6 TG curves of polyglycerol esters having stearic acid with various degrees of esterification.

weight loss $\mathrm{PG}-\mathrm{C} 16$ initiated at $201^{\circ} \mathrm{C}$, subsequently proceeded rapidly until $350^{\circ} \mathrm{C}$ and was finished at $490^{\circ} \mathrm{C}$. The weight loss pattern in the temperature region above $350^{\circ} \mathrm{C}$ was complicated than $P G$ with higher degrees of polymerization. The weight loss of PG-C12 and PG-C18 initiated at $197^{\circ} \mathrm{C}$ and $208^{\circ} \mathrm{C}$, and the initial temperature of weight loss were shifted to higher temperature side with an increase of carbon number of acyl groups, though this tendency was not so obvious as that observed in the case of sucrose monoester of fatty acids ${ }^{6}$. After the initiation of weight loss, the weight loss patterns of PG-C12 and PG-C18 were closely similar to PG-C16.

Fig.-6 showed the TG curves of PG-Mo, PG-Tr and PG-He, among the PGFE with different degree of esterification. The weight loss of PG-Mo initiated at $208^{\circ} \mathrm{C}$ and was finished at $513^{\circ} \mathrm{C}$. The weight loss of PG-Tr initiated at $211^{\circ} \mathrm{C}$, proceeded rapidly at about $300^{\circ} \mathrm{C}$ and was finished at $544^{\circ} \mathrm{C}$. The TG curve of PG-Tr from 300 to $360^{\circ} \mathrm{C}$ was located at lower temperature region than that of $\mathrm{PG}-\mathrm{Mo}$ in spite of initial temperature of weight loss of $\mathrm{PG}-\mathrm{Tr}$ was higher than PG-Mo. The weight loss of PG-He with higher degree of esterification initiated at $197^{\circ} \mathrm{C}$. Its $\mathrm{TG}$ curve was located at lower temperature region than $\mathrm{PG}-\mathrm{Mo}$ and $\mathrm{PG}-\mathrm{Tr}$ until about $350^{\circ} \mathrm{C}$. However, the weight loss proceeded slowly at a temperature range of $350 \sim 400^{\circ} \mathrm{C}$ and then the $\mathrm{TG}$ curve were shifted to higher temperature side than those of PG-Mo and PG-Tr. The weight loss of PG-Di initiated at $209^{\circ} \mathrm{C}$ and its TG curve was located at the intermediate of those of PG-Mo and PG-Tr. The weight loss of PG-Pe initiated at $207^{\circ} \mathrm{C}$ and proceede somewhat rapidly until about $300^{\circ} \mathrm{C}$ than that of PG-Tr. However, the weight loss pattern of $\mathrm{PG}-\mathrm{Pe}$ in high temperature region above $300^{\circ} \mathrm{C}$ was closely similar to PG-He and its TG curve was located at the intermediate position of those of PG-Tr and PG-He.

As mentioned above, the initial temperature of weight loss and TG curves of PG-Mo, -Di and - Tr were shifted to higher temperature side, accompanied with the increase of the thermostability, with an increase of degree of esterification. The initial temperature of weight loss of PG-Pe and PG-He with further higher degrees of esterification were shifted to lower temperature side and the thermostability were decreased. However, TG curves of PGFE with different degrees of esterification at a temperature range of $300 \sim 400^{\circ} \mathrm{C}$ showed characteristic weight loss pattern, and these TG curves from 350 to $400^{\circ} \mathrm{C}$ were shifted to higher temperature side with an increase of degree of esterification.

\subsection{Thermostability of PGFE determined by isothermal TG}

The decomposition time from initial to that with $5 \%$ of weight loss in isothermal TG was regarded as the heat resisting time, and hence, the thermostability of PGFE could be evaluated by the heat resisting time as described previously ${ }^{6}$. In Fig.-7, the heat resisting time of PG-C12, C16 and $\mathrm{C} 18$ were plotted against the various temperatures. In each temperature, there were found any significant correlation between the heat resisting time of the samples and their carbon numbers. This tendency agreed well with the temperature with $5 \%$ of weight loss determined by the dynamic programmed TG. When the thermostability of these PG monoesters were compared with sucrose monoester of fatty acids with the corresponding acyl groups ${ }^{6)}$, the temperature with the same heat resisting time of the former was higher about $50^{\circ} \mathrm{C}$ 


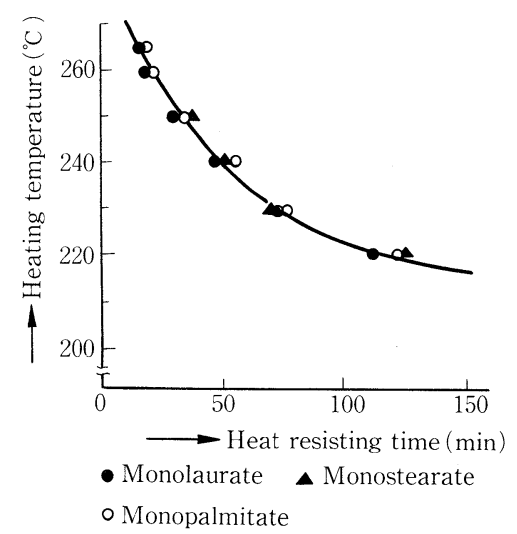

Fig.-7 Plots of heat resisting time vs, heating temperature for polyglycerol monoacyl esters with various carbon numbers of acyl group.

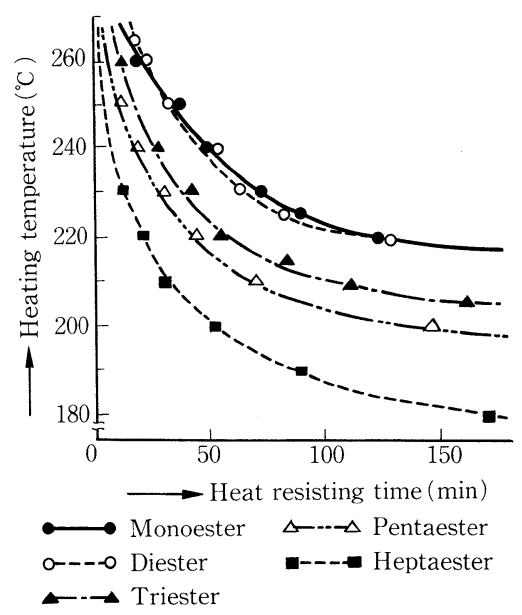

Fig.-8 Plots of heat resisting time vs. heating temperature for polyglycerol esters having stearic acid with various degrees of esterification.

than of the latter, and the thermostability was very excellent.

The heat resisting time of PGFE with different degree of esterification under the various experimental temperatures were plotted against the degree of esterification as shown in Fig.-8. The heat resisting time of PG-Mo and -Di at each experimental temperature were also the same with each other, and their thermostability were the most excellent. The temperature with $5 \%$ weight loss determined by the dynamic programmed TG showed almost the same tendency with that mentioned above. The temperature with $5 \%$ weight loss of PG-Tr, -Pe, and -He determined by the dynamic programmed TG agreed well with the tendency of the heat resisting time determined by the isothermal TG. However, when compared with the temperature with the same heat resisting time, PG-He, which had the lowest thermostability, was higher about $20^{\circ} \mathrm{C}$ than that of the monoester which exhibited the highest thermostability among sucrose esters ${ }^{6}$.

From the foregoings, it can be summarized that the TG curves of $P G$ with different degree of polymerization determined by the dynamic programmed TG were shifted to higher temperature side with an increase of degree of polymerization. Thus, from the ratio of the weight loss at various temperature ranges of a commercial PG, it can be determined the water and monoglycerol contents simultaneously, and can be estimated roughly the polymer composition. On the other hand, the initial temperature of weight loss of PGFE was shifted to higher temperature side with an increase of carbon number of the acyl groups. Although the initial temperature of weight loss of PGFE did not correlate with their degree of esterification, their TG curves were shifted to higher temperature side with an increase of degree of esterification in a temperature range of 350 $400^{\circ} \mathrm{C}$. This weight loss behavior showed characteristic pattern to individual PGFE. These facts suggest that the components of $\mathrm{PG}$, carbon number of acyl groups, and the degree of esterification in PGFE might roughly be estimated by the dynamic programmed TG. When the carbon number of acyl groups and the degree of esterification in PGFE were the same, it is assumed that the initial temperature of weight loss of the PGFE would be shifted to higher temperature side with an increase of degree of polymerization of PG moiety in PGFE. This is because of the fact that the initial temperature of weight loss of PG was shifted to higher temperature side with an increase of degrees of polymerization. Therefore, this technique reported here is expected to be sufficiently utilized in the qualitative control in a production process, though it is inferior to the GLC and HPLC method in the accuracy. The thermostability of PGFE evaluated by the isothermal TG was almost the same with one another, with no influence from carbon number of acyl groups. It showed further that the thermostability of PGFE decreased with an increase of 
degree of esterification. When compared the thermostability of individual PGFE with sucrose ester of fatty acids ${ }^{6}$, PGFE showed the same thermostability at higher temperature about 20 or $50^{\circ} \mathrm{C}$ than the latter at the same heat resisting time. Accordingly, the technique reported here might be usefull in the qualitative evaluation of an emulsifier which is used the heating in the preparation of a processed food product.

\section{Acknowledgements}

We thank Sakamoto Chemical Industries Co., Ltd., for cooperation gift of PGFE. We also thank Dr. H. Kanematsu, asistant director of Tokyo laboratory, Japan Institute of Oils \& Fats, Other Foods Inspection (Foundation), and Dr. T. Akihisa, Faculty of Science and Thechnology, Nihon University, for their helpful advice.

(Received Aug. 22, 1989)

\section{References}

1) 1) V.K. Babayan, J. Am. Oil Chem. Soc., 41, 434 (1964).

2) K. Matsushita and Y.Shioyama, J. Jpn. Oil Chem. Soc. (Yukagaku), 35, 71 (1986).

3) "Official and Commentary Note of Food Addition, 5th (Jpn)" Hirokawa Syoten, Tokyo (1987) p. 258.

4) M. R. Sahasrabudhe, J. Am. Oil Chem. Soc., 44, 376 (1967)

5) N. Gsrti and A. Aserin, J. Liquid Chromatogr. , 4, 1173 (1981).

6) T.Ushikusa, T.Maruyama, I. Niiya and M. Okada, J. Jpn. Oil Chem. Soc. (Yukagaku), 39, 38 (1990).

7) Jpn. Oil Chem. Soc., "Standard Method for the Analysis of Oil, Fat and Derivatives" 2.2.2.471.

8) Jpn. Oil Chem. Soc., "Standard Method for the Analysis of Oil, Fat and Derivatives" 2.2.3.171.

9) Jpn. Oil Chem. Soc., "Handbook of Oil and
Fat Chemical (Jpn.) Maruzen, Tokyo (1971) p. 131.

10) T.Ushikusa, T. Maruyama, I. Niiya, and T. Matsumoto, J. Jpn. Oil Chem. Soc. (Yukagaku), 37, 742 (1988).

11) Y.Shioyama and K. Matsushita, Yushi, 33, 67 (1980).

ポリグリセリン及びポリグリセリン脂肪酸エ ステルの熱分解挙動及びその熱安定性

牛草寿昭* · 丸山武紀* · 新谷 勛* · 岡田正和 $* *$

* 財団法人 日本食品油脂検查協会（ 103 東京都中央区 日本橋浜町 3-27-8)

**広島大学生物生産学部 ( ₹724 東広島市西条町大字下見)

昇温熱重量測定（TG）を用いて重合度の異なるポリ グリセリン $(\mathrm{PG})$ 及び市販の $\mathrm{PG}$ 並びにアシル基炭素 数及びエステル化度の異なるポリグリセリン脂肪酸エス テル (PGFE) の減量挙動について比較した。さらに $\mathrm{PG}$ については各温度間の減量率と組成成分との関係に ついても検討した。また，昇温 TGによる減量開始温 度及び恒温 TGによる減量開始から $5 \%$ 減量するまで に要した分解時間により PGFEの熱安定性を評価し た。

1） PGの昇温 TGでは，重合度が増加するにした がってTG曲線は高温側に移行し, 熱安定性は向上し た。水分蒸発後の市販 PG の TG曲線は重合物の組成 により特有の減量パターンを示した。

2) $\mathrm{PG}$ の昇温 TGにおいて室温から， $150^{\circ} \mathrm{C}, 150$ から $250^{\circ} \mathrm{C} ， 250$ から $300^{\circ} \mathrm{C}$ 及び 300 から $350^{\circ} \mathrm{C}$ 間の減 量率は水，モノグリセリン，ジとトリグリセリンの和及 びテトラとペンタグリセリンの和とそれぞれ相関した。

3） PGFEの昇温 TGでは，アシル基炭素数が多く なるにしたがって娍量開始温度は高温側に移行した。し かし，エステル化度の異なる PGFE は減量開始温度と エステル化度は相関しないものの, 300 から $400^{\circ} \mathrm{C}$ 間の TG 曲線は特有の減量パターンを示した。

4) 恒温 TG では，各測定温度における PGFEの耐 熱時間はアシル基炭素数に影響されずほぼ等しい。しか し，エステル化度が高くなるにしたがって PGFE の耐 熱時間は短くなり，熱安定性は低下した。 